\title{
Erratum to: Multiscale Modelling in Sheet Metal Forming
}

\author{
Dorel Banabic
}

\section{Erratum to:}

\section{Banabic (ed.), Multiscale Modelling in Sheet}

\section{Metal Forming, ESAFORM Bookseries on Material Forming, DOI 10.1007/978-3-319-44070-5}

The original version of the book was inadvertently published with incorrect affiliation of Jerzy Gawad, Philip Eyckens, Albert van Bael and Paul van Houte in Chap. 1 and Chap. 3, Chap. 5 was published without inclusion of the contributor's name "Philip Eyckens", and in Chap. 7, Equation 7.75 content was published incorrectly. The erratum chapters and the book have been updated with the changes.

The updated original online version for this book can be found at 10.1007/978-3-319-44070-5

D. Banabic $(\bowtie)$

CERTETA Research Center, Technical University of Cluj-Napoca,

Cluj-Napoca, Romania

e-mail: banabic@tcm.utcluj.ro 